\title{
Kinetics of Hydrogenolysis of Isobutene in the Presence of Deuterium
}

\author{
Yoshinobu Yoкоmori,* Hiromichi Arai* and Hiroo Tominaga*
}

\begin{abstract}
Pyrolysis of isobutene in the temperature range from 948 to $1,023 \mathrm{~K}$ was studied in the presence of hydrogen or deuterium using an atmospheric flow reactor. The overall rate of isobutene decomposition could be expressed by 1.5 order rate equations. The overall kinetic isotope effect $\left(k_{\mathrm{H}_{2}}\right) /\left(k_{\mathrm{D}_{2}}\right)$ was 2.54-1.72 in the temperature range studied. The distribution of deuterated products was analyzed that gave some evidence in support of the free radical chain mechanism previously proposed. R.R.K.M. theory was applied to calculate the rate of hot isobutyl radical decomposition.
\end{abstract}

\section{Introduction}

Hydrogenolysis reactions of propylene ${ }^{1), 2)}$, isobutene $^{3)}$, toluene ${ }^{4) ~ 9)}$, and xylenes ${ }^{9) ~ 11) ~}$ showed many striking similarities ${ }^{1,5), 12)}$. Moreover, the rates of these reactions could be expressed as first order with respect to olefins or the methyl-substituted aromatics and a half order with respect to hydrogen, and comparable Arrhenius parameters were obtained and ranked in a definite range. The rates of these reactions are, therefore, generally interpreted in terms of a common free radical chain mechanism. In our previous study, the kinetics and mechanism of hydrogenolysis of propylene ${ }^{2}$ was investigated in the presence of deuterium. The present study was performed to obtain more detailed information on the mechanism of isobutene pyrolysis in the presence of hydrogen (1) or deuterium in comparison with that of propylene.

$$
\begin{aligned}
& \mathrm{CH}_{2}=\mathrm{C}\left\langle\mathrm{CH}_{3} \underset{k}{\stackrel{\mathrm{CH}_{3}}{\longrightarrow}} \mathrm{CH}_{2}=\mathrm{CHCH}_{3}+\mathrm{CH}_{4} \underset{k^{\prime}}{\stackrel{\mathrm{H}_{2}}{\longrightarrow}}\right. \\
& \mathrm{CH}_{2}=\mathrm{CH}_{2}+2 \mathrm{CH}_{4}
\end{aligned}
$$

The kinetic isotope effect and deuterium distribution in the reaction products were discussed with special interest in the behavior of the hot alkyl radicals produced by addition of hydrogen atom to the olefins.

\section{Experimental}

\subsection{Materials}

Cylinder isobutene, $99.9 \mathrm{~mol} \%$ purity was used without further purification. Cylinder hydrogen, $99.9 \mathrm{~mol} \%$ was used after purification over Deoxo catalyst and zeolite 13Y. Cylinder deuterium, $99.5 \mathrm{~mol} \%$ purity containing $\mathrm{H}_{2}, \mathrm{HD}$, and nitrogen

Received Sept. 21, 1977.

* Department of Synthetic Chemistry, Faculty of Engineering, The University of Tokyo (7-3-1, Hongo, Bunkyoku, Tokyo 113) as principal impurities was purified over $\mathrm{Pd} / \mathrm{Al}_{2} \mathrm{O}_{3}$ and zeolite 13Y. Cylinder nitrogen, $99.99 \mathrm{~mol} \%$ was used without further purification. A conventional atmospheric flow reactor was employed for pyrolysis ${ }^{2}$. Pyrolysis runs were carried out under the following conditions: temperature, 948 - $1,023 \mathrm{~K}$; residence time, $1.0-4.5 \mathrm{sec}$; hydrogen or deuterium/isobutene mole ratio, up to approximately 10 .

\subsection{Analysis}

Gaseous products consisting of hydrocarbons ranging from methane to $\mathrm{C}_{4}$ 's, were analyzed by gas chromatography using a sebaconitrile column $(7 \mathrm{~m}$ long) connected to an activated alumina column (0.5 $\mathrm{m}$ long) at $40^{\circ} \mathrm{C}$ with nitrogen as a carrier gas. The distribution of deuterated products were determined by gas chromatographic-mass spectrography using a porapak $Q$ column (1 m long) at $40-50^{\circ} \mathrm{C}$ with helium as a carrier gas. Pattern coefficients of methane, ethane, propylene, isobutene were obtained from mass spectral data of API Research Project 44. The fragmentation modes of deuterated isobutenes and deuterated propylenes were assumed to be the same as those of isobutene- $\mathrm{d}_{0}$, and propylene- $\mathrm{d}_{0}$. It was also assumed that all of the $\mathrm{d}_{0}, \mathrm{~d}_{1}$, and $\mathrm{d}_{2}$ compounds had the same sensitivity.

\section{Results}

Tables 1, and 2 show the experimental results in the presence of hydrogen or deuterium. The overall rate of isobutene decomposition could be expressed by 1.5 order rate equation as follows;

$$
-\frac{d\left[i-\mathrm{C}_{4} \mathrm{H}_{8}\right]}{d t}=k_{\text {obs. }}\left[i-\mathrm{C}_{4} \mathrm{H}_{8}\right]\left[\mathrm{H}_{2} \text { or } \mathrm{D}_{2}\right]^{1 / 2}
$$

Arrhenius parameters were obtained as follows;

$$
\begin{aligned}
\left(k_{\text {obs. }}\right)_{\mathrm{H}_{2}}= & 10^{13.6 \pm 0.4} \exp (-62,000 \pm 4,000 / \mathrm{RT}) \\
\left(k_{\text {obs. }}\right)_{\mathrm{D}_{2}}= & 10^{15.1 \pm 0.5} \exp (-72,000 \pm 4,000 / \mathrm{RT}) \\
& l^{1 / 2} \mathrm{~mol}^{-1 / 2} \mathrm{sec}^{-1}
\end{aligned}
$$


Table 1 Pyrolysis of Isobutene in the Presence of Hydrogen

\begin{tabular}{lrrrrrr}
\hline Run No. & 3 & 4 & 5 & 1 & 2 & 6 \\
Temperature T/K & 1,023 & 1,023 & 998 & 973 & 973 & 948 \\
$\mathrm{H}_{2} / i-\mathrm{C}_{4} \mathrm{H}_{8}$ & 9.9 & 10.1 & 10.5 & 8.9 & 11.0 & 9.3 \\
Reaction Time t/sec & 2.0 & 1.2 & 1.9 & 1.3 & 2.1 & 4.5 \\
Conversion \% & 49.9 & 24.4 & 18.3 & 8.5 & 11.3 & 9.2 \\
Products, moles from isobutene feed 100 moles & & & & & \\
$\quad$ methane & 87.6 & 37.0 & 23.5 & 6.5 & 8.5 & 7.9 \\
$\quad$ ethylene & 19.1 & 5.2 & 3.1 & 0.8 & 1.0 & 0.9 \\
$\quad$ ethane & 2.5 & 0.6 & 0.4 & - & - & 0.1 \\
$\quad$ propylene & 26.9 & 16.7 & 13.3 & 6.9 & 7.7 & 5.8 \\
$\quad$ propane & 1.8 & 1.0 & 0.9 & - & 0.6 & 0.4 \\
$\quad$ isobutane & 1.7 & 1.4 & 2.0 & 1.1 & 2.0 & 1.9 \\
\hline
\end{tabular}

Table 2 Pyrolysis of Isobutene in the Presence of Deuterium

\begin{tabular}{|c|c|c|c|c|c|c|c|}
\hline Run No. & 8 & 7 & 9 & 10 & 12 & 11 & 13 \\
\hline Temperature $\mathrm{T} / \mathrm{K}$ & 1,023 & 1,023 & 998 & 998 & 973 & 973 & 948 \\
\hline $\mathrm{D}_{2} / i-\mathrm{C}_{4} \mathrm{H}_{8}$ & 10.1 & 9.9 & 9.5 & 10.2 & 10.3 & 9.6 & 10.6 \\
\hline Reaction Time $t / s e c$ & 2.0 & 1.0 & 2.1 & 1.1 & 4.2 & 2.2 & 4.2 \\
\hline Conversion $\%$ & 32.3 & 15.6 & 13.7 & 5.6 & 11.2 & 5.4 & 4.8 \\
\hline \multicolumn{8}{|c|}{ Products, moles from isobutene feed 100 moles } \\
\hline methane & 53.8 & 23.5 & 20.6 & 7.4 & 14.8 & 6.3 & 4.6 \\
\hline ethylene & 7.7 & 2.1 & 2.0 & 0.5 & 1.3 & 0.5 & 0.4 \\
\hline ethane & 0.7 & 0.2 & 0.2 & $0.0_{8}$ & 0.1 & $0.0_{9}$ & $0.0_{8}$ \\
\hline propylene & 20.5 & 11.4 & 10.6 & 4.3 & 8.4 & 4.1 & 3.3 \\
\hline propane & 0.5 & 0.4 & 0.3 & 0.1 & 0.2 & 0.2 & 0.2 \\
\hline isobutane & 1.1 & 1.0 & 1.1 & 0.6 & 1.1 & 0.7 & 0.9 \\
\hline
\end{tabular}

The rate constant obtained in the presence of hydrogen was in fairly good agreement with that previously obtained at this laboratory ${ }^{13}$. The overall kinetic isotope effect is defined here as the ratio of the overall rate constants for hydrogen and deuterium. The value $\left(k_{\mathrm{obs}}\right)_{\mathrm{H}_{2}} /\left(k_{\mathrm{obs}} .\right)_{\mathrm{D}_{2}}$ was found to decrease linearly from 2.54 to 1.72 in the temperature range studied, namely, 948-1,023 K. Figs. 1, 2, and 3 show the change in deuterium distribution in the reaction products, methane, propylene and isobutene, as a function of isobutene hydrodemethylated.

\section{Discussion}

Hydrogenolytic demethylation mechanism of toluene and propylene have been extensively studied and their results suggest that the elementary reactions shown below may constitute the chain mechanism of isobutene hydrogenolysis.

$$
\begin{aligned}
& i-\mathrm{C}_{4} \mathrm{H}_{8} \stackrel{\mathrm{a}}{\mathrm{b}}={ }_{\mathrm{CH}_{2}^{\prime}}^{\mathrm{CH}_{3}} \mathrm{CH}_{2}+\mathrm{H} \cdot \\
& \mathrm{H} \cdot+i-\mathrm{C}_{4} \mathrm{H}_{8}=\frac{\mathrm{c}}{\mathrm{d}}=\mathrm{H}_{2}+{ }_{\mathrm{CH}_{2}}^{\mathrm{CH}_{3}} \mathrm{C}=\mathrm{CH}_{2} \\
& \mathrm{H} \cdot+i-\mathrm{C}_{4} \mathrm{H}_{8} \stackrel{\mathrm{e}}{\longrightarrow}-\mathrm{C}_{3} \mathrm{H}_{6}+\cdot \mathrm{CH}_{3}
\end{aligned}
$$

$$
\begin{aligned}
& \cdot \mathrm{CH}_{3}+\mathrm{H}_{2} \mathrm{f}=\mathrm{CH}_{4}+\mathrm{H} \cdot \\
& \cdot \mathrm{CH}_{3}+i-\mathrm{C}_{4} \mathrm{H}_{8} \stackrel{\mathrm{g}}{=} \mathrm{CH}_{4}+\underset{ }{\rightleftharpoons}{ }_{\mathrm{CH}_{2}^{\prime}} \mathrm{C}=\mathrm{CH}_{2}
\end{aligned}
$$

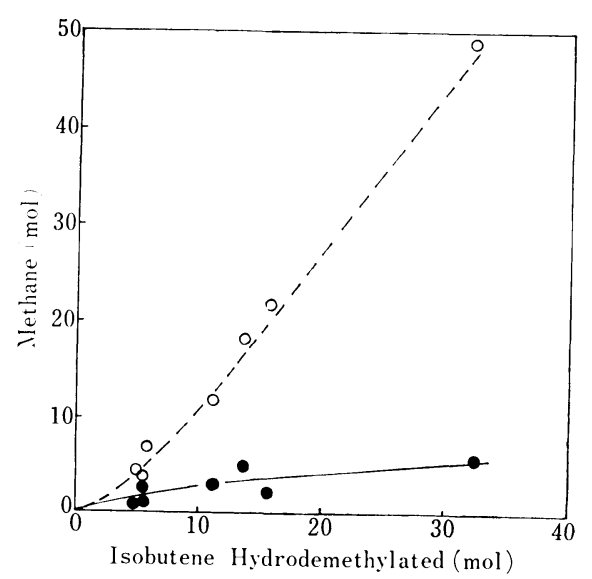

Temp. $948 \sim 1,023 \mathrm{~K}, \mathrm{D}_{2} / i-\mathrm{C}_{4} \mathrm{H}_{8}=$ ca. 10

: Methane- $\mathrm{d}_{0}, \mathrm{O}: \mathrm{d}_{1}$

Fig. 1 Deuterium Distribution in Methane

\subsection{D-distribution}

The experimental findings are shown in Figs. 1 3 and their implications in terms of the reaction mechanism concerned are as follows.

First of all, Fig. 1 shows the number of moles 
of methanes formed, namely, methane- $\mathrm{d}_{0}$ and $\mathrm{d}_{1}$, are approximately 1.5 times that of isobutene hydrodemethylated. This is due to the additional formation of methanes by successive demethylation of propylene to give ethylene as shown by (1). The kinetic analysis of the product pattern, namely, the stoichiometry of olefins and methane, indicates that the ratio of the specific rates is given by $\mathrm{k} / \mathrm{k}^{\prime}=1.6$, which is in good agreement with that obtained previously with hydrogen ${ }^{13}$. The formation of methane- $\mathrm{d}_{0}$ is noteworthy, since it gives strong empirical evidence of the existence of the elementary reaction (g), which was included in the free radical chain mechanism previously proposed based solely on the evaluation of the relative rates of the relevant elementary reactions. Another route to methane formation is naturally,

$$
\cdot \mathrm{CH}_{3}+\mathrm{D}_{2} \stackrel{\mathrm{f}^{\prime}}{\longrightarrow} \mathrm{CH}_{3} \mathrm{D}+\mathrm{D} \text {. }
$$

The ratio of methane- $\mathrm{d}_{1}$ and $\mathrm{d}_{0}$ formed is, therefore, determined by

$$
\frac{\left[d_{1}-\text { methane }\right]}{\left[d_{0}-\text { methane }\right]}=\frac{k_{f^{\prime}}\left[\mathrm{D}_{2}\right]}{k_{g}\left[i-\mathrm{C}_{4} \mathrm{H}_{8}\right]},
$$

and it is 10 as experimentally obtained. Since $\left[\mathrm{D}_{2}\right] /$ $\left[i-\mathrm{C}_{4} \mathrm{H}_{8}\right]$ is in the range of $10.7-10.9, k_{f^{\prime}} \mid k_{g}$ should be nearly equal to one. This is in accordance with the fact that methyl radical is so active that the rate of hydrogen abstraction is not largely dependent on the bond dissociation energy of the substrate.

Secondary, a larger amount of propylene- $\mathrm{d}_{0}$ than propylene- $d_{1}$ is formed particularly in the initial stage of the reaction, or at lower levels of conversion of isobutene as shown in Fig. 2. This is accounted for by the predominance of hydrogen

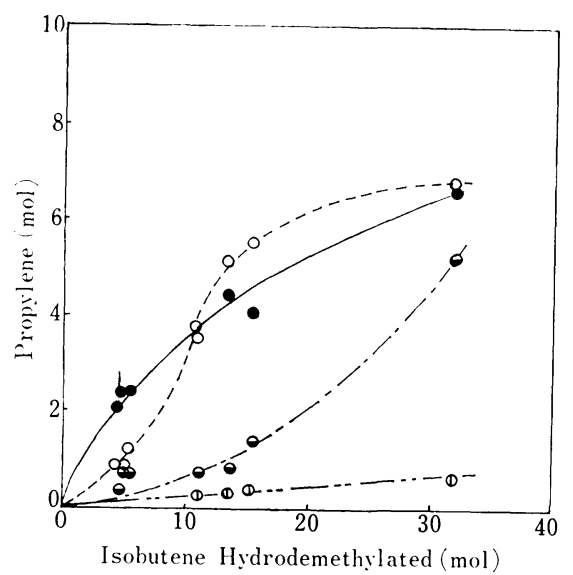

Temp. 948 1, $023 \mathrm{~K}, \mathrm{D}_{2} / i-\mathrm{C}_{4} \mathrm{H}_{8}=$ ca. 10

: Propylene- $\mathrm{d}_{0}, \bigcirc: \mathrm{d}_{1}, \ominus: \mathrm{d}_{2}, \Phi: \mathrm{d}_{3}$

Fig. 2 Deuterium Distribution in Propylene

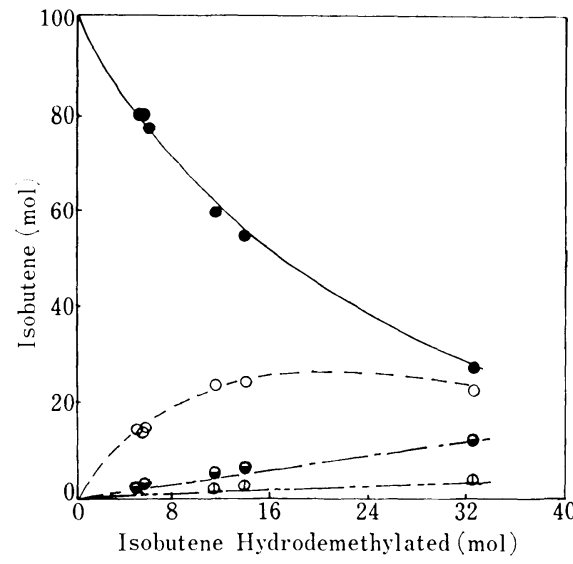

Temp. 948 1, $023 \mathrm{~K}, \mathrm{D}_{2} / i-\mathrm{C}_{4} \mathrm{H}_{8}=$ ca. 10

: Isobutene- $d_{0}, \bigcirc: d_{1}, \odot: d_{2}, \Phi: d_{3}$

Fig. 3 Deuterium Distribution in Isobutene

atom over deuterium atom even in the reaction system of $\mathrm{D}_{2}$-isobutene. As is shown in Figs. 2 and $\mathbf{3}$, the rate of deuteration of isobutene (via terminal addition to isobutene) is much faster than hydrodemethylation (via internal addition). The former reaction is associated with the formation of hydrogen atom in the manner,

$$
\mathrm{D} \cdot+i-\mathrm{C}_{4} \mathrm{H}_{8} \stackrel{i}{\longrightarrow} i-\mathrm{C}_{4} \mathrm{H}_{7} \mathrm{D}+\mathrm{H} \text {. }
$$

Accordingly, the deuterium atom, D, produced by the reactions, $\left(f^{\prime}\right)$ and $\left(d^{\prime}\right)$,

$$
i-\mathrm{C}_{4} \mathrm{H}_{7} \cdot+\mathrm{D}_{2} \stackrel{d^{\prime}}{\longrightarrow} i-\mathrm{C}_{4} \mathrm{H}_{7} \mathrm{D}+\mathrm{D} \text {. }
$$

is largely converted into hydrogen atom through the reaction (i) before they attack isobutene by reaction (e), i.e., internal addition to the olefin. In the advanced stages of isobutene conversion, the rate of propylene- $d_{1}$ formation becomes larger than that of $d_{0}$. This is ascribed to the increase in isobutene- $d_{1}$ which gives propylene- $d_{1}$ upon hydrogenolysis by the hydrogen atom. The ratio of isobutene- $d_{1}$ and propylene- $d_{1}$ in the initial stages of reaction, gives the ratio of the rates of terminal and internal addition. In this study, this ratio is 7.2 which is in fairly good agreement with the results found in literature ${ }^{17}$.

In brief, these experimental results of pyrolysis of isobutene in deuterium revealed a mechanism of hydrogenolysis that supported the proposed elementary reactions and revealed several findings which had not been disclosed in the pyrolysis of the olefin in hydrogen. The important elementary reactions in the presence of deuterium are summarized as follows;

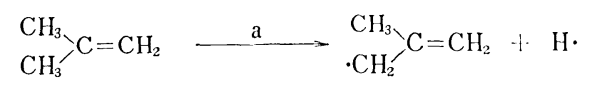


'Table 3 The Rates of Decomposition of Hot Butyl Radicals Calculated by R. R. K. M. Theory

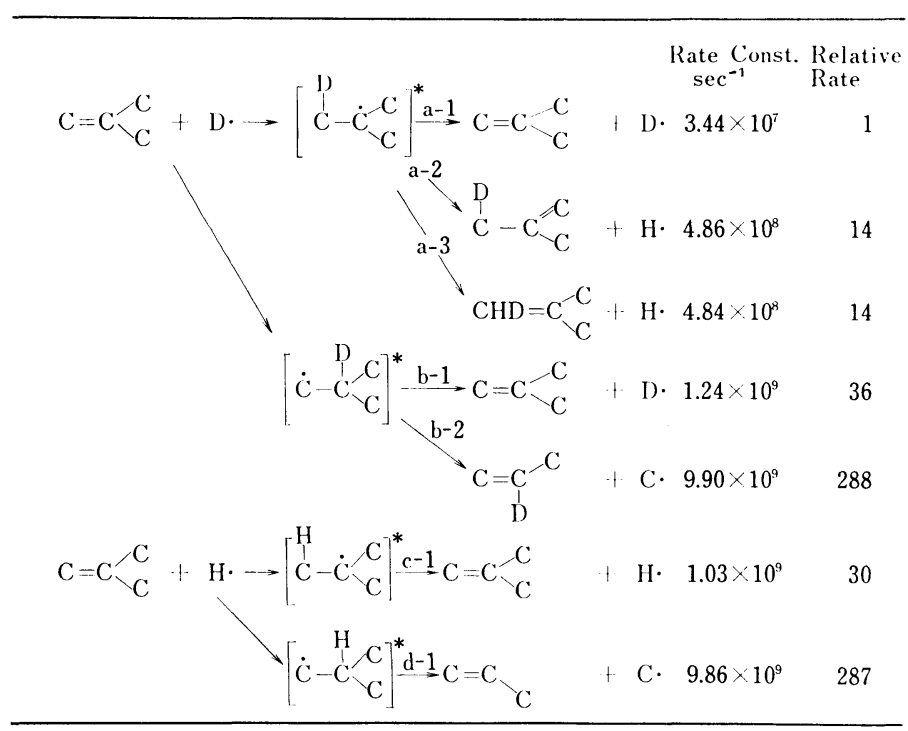

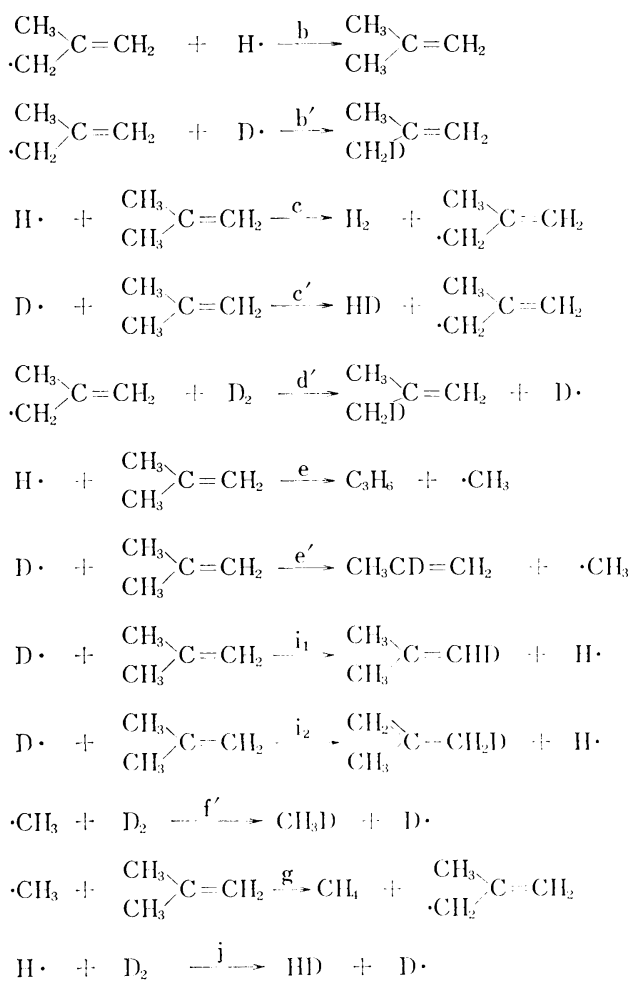

\subsection{Kinetic Isotope Effect}

By analogy to propylene ${ }^{2)}$ and toluene ${ }^{4) \sim 6 \text { ) }}$ hydrogenolysis, the overall rate constant is given by,

$$
\left(k_{\mathrm{obs} .}\right)_{\mathrm{H}_{2}}=k_{e}\left(\frac{k_{\mathrm{a}} \cdot k_{\mathrm{d}}}{k_{\mathrm{b}} \cdot k_{\mathrm{c}}}\right)^{1 / 2}
$$

No kinetic isotope effect is expected for reaction (a), and it is very small for reactions $(b),\left(b^{\prime}\right),(c)$, and $\left(c^{\prime}\right)$. Since 2-methyl allyl radical is inactive due to its resonance stability, the zero point energy difference between $\mathrm{H}-\mathrm{H}$ and D-D bond possibly con- tributes to the kinetic isotope effect of $k_{\mathrm{d}}$ vs. $k_{\mathrm{d}^{\prime}}$. Since 2-methyl allyl radical is more stable than allyl radical, the kinetic isotope effect in the case of isobutene pyrolysis is larger than that for propylene ${ }^{2}$. This is supported by the observed kinetic isotope effect, $\left(k_{\mathrm{obs}}\right)_{\mathrm{H}_{2}} /\left(k_{\mathrm{obs}} .\right)_{\mathrm{D}_{2}}$, for,

$\begin{array}{lrrrr}\text { Temperature K; } & 1,023 & 998 & 973 & 948 \\ \mathrm{C}_{3} \mathrm{H}_{6} ; & 1.68 & 1.81 & 1.96 & 2.13 \\ i-\mathrm{C}_{4} \mathrm{H}_{8} ; & 1.72 & 1.94 & 2.21 & 2.54\end{array}$

\subsection{R.R.K.M. Galculation}

More attention should be paid to reactions (e), $\left(\mathrm{e}^{\prime}\right),\left(\mathrm{i}_{1}\right)$, and $\left(\mathrm{i}_{2}\right)$. They involve addition of deuterium or hydrogen atom to give hot alkyl radicals and their unimolecular decomposition to yield a variety of products. The decomposition rate constants of hot tert-butyl and isobutyl radical were computed by R.R.K.M. theory ${ }^{\mathbf{1 4})}$, and thermochemical data were obtained from the literature ${ }^{15), 16)}$. Vibration models and other parameters, with some modification, were mostly adopted from the work by Rabinovitch et al. The calculated rate constants presented in Table 3 are those at $998 \mathrm{~K}$ and atmospheric pressure. It is obvious the rate of hot isobutyl radical decomposition to give propylene is much faster than that of hot tert-butyl radical to give deuterated isobutene. Accordingly, the experimental findings that the rate of isobutene deuteration is much faster than that of isobutene hydrodemethylation should be ascribed to the fact that the terminal addition of hydrogen atom to isobutene to produce tert-butyl takes place more readily than the internal addition to give isobutyl radical. In other words, the rate of 
hydrogen atom addition, terminal or internal, substantially determines the rate of deuteration or demethylation.

\section{Conclusions}

(1) The kinetic isotope effect observed on the overall rate of hydrogenolytic demethylation of isobutene in the presence of deuterium is interpreted in terms of a free radical chain mechanism.

(2) Deuterium distribution in the reaction products supports the mechanism proposed.

(3) The hydrogen atom produced via isobutene deuteration plays an important role in hydrogenolysis even in the presence of deuterium.

(4) The rate of hydrogen atom addition, terminal or internal, substantially determines the rate of deuteration or demethylation.

\section{References}

1) Amano, A., Uchiyama, M., J. Phys. Cinem., 67, 1242 (1963).

2) Yokomori, Y., Arai, H., Tominaga, H., A G S symposium series 32, ISSN 0097-6156, "Industrial and Laboratory Pyrolysis”, pp. 84 98 (1976).
3) Kunugi, 'T., Tominaga, H., Abiko, S., Uchara, K., Ohno, 'T., Kogyo Kagaku Zasshi, 70, 1477 (1967).

4) Matsui, H., Amano, A., Tokuhisa, H., Bull. Japan Petrol. Inst., 1, 67 (1959).

5) Amano, A., 'Tominaga, H., 'Tokuhisa, H., ibid., 7, 59 (1965).

6) 'Tominaga, H., Arai, H., Kunugi, T., Amano, A., Uchiyama, M., ibid., 43, 3658 (1970).

7) Burr, J. G., Meyer, R. A., Strong, J. D., J. Am. Chem. Soc., 86, 3846 (1964)

8) Tsuchiya, A., Hashimoto, A., Tominaga, H., Masamune, S., Bull. Japan Petrol. Inst., 1, 73 (1959).

9) Mori, H., Hashimoto, A., Tominaga, H., World Petrol. Congr. Proc. 6th, Frankfurt, Germany, 131 (1963).

10) Burr, J. G., Strong, J. D., J. Am. Chem. Soc., 86, 5065 (1964).

11) Tauchi, A., Bull. Japan Petrol., 2, 85 (1960).

12) Benson, S. W., Show, R., J. Chem. Phys., 47, 4052 (1967).

13) Tominaga, H., Arai, H., Moghul, K. A., Takahashi, N., Kunugi, T., Kogyo Kagaku Zasshi, 74, 371 (1971).

14) Rabinovitch, B. S., Setser, D. W., Adv. Photochem., 3, 1 (1964).

15) Falconer, W. E., Rabinovitch, B. S., Guetanovitch, R. J., J. Chem. Phys., 39, 40 (1963).

16) Rabinovitch, B. S., Kubin, R. F., Harrington, R. E., J. Chem. Phys., 38, 405 (1963).

17) Gvetanovitch, R. J., Adv. Photochem., 1, 115 (1961).

Appendix Vibration Models (1)

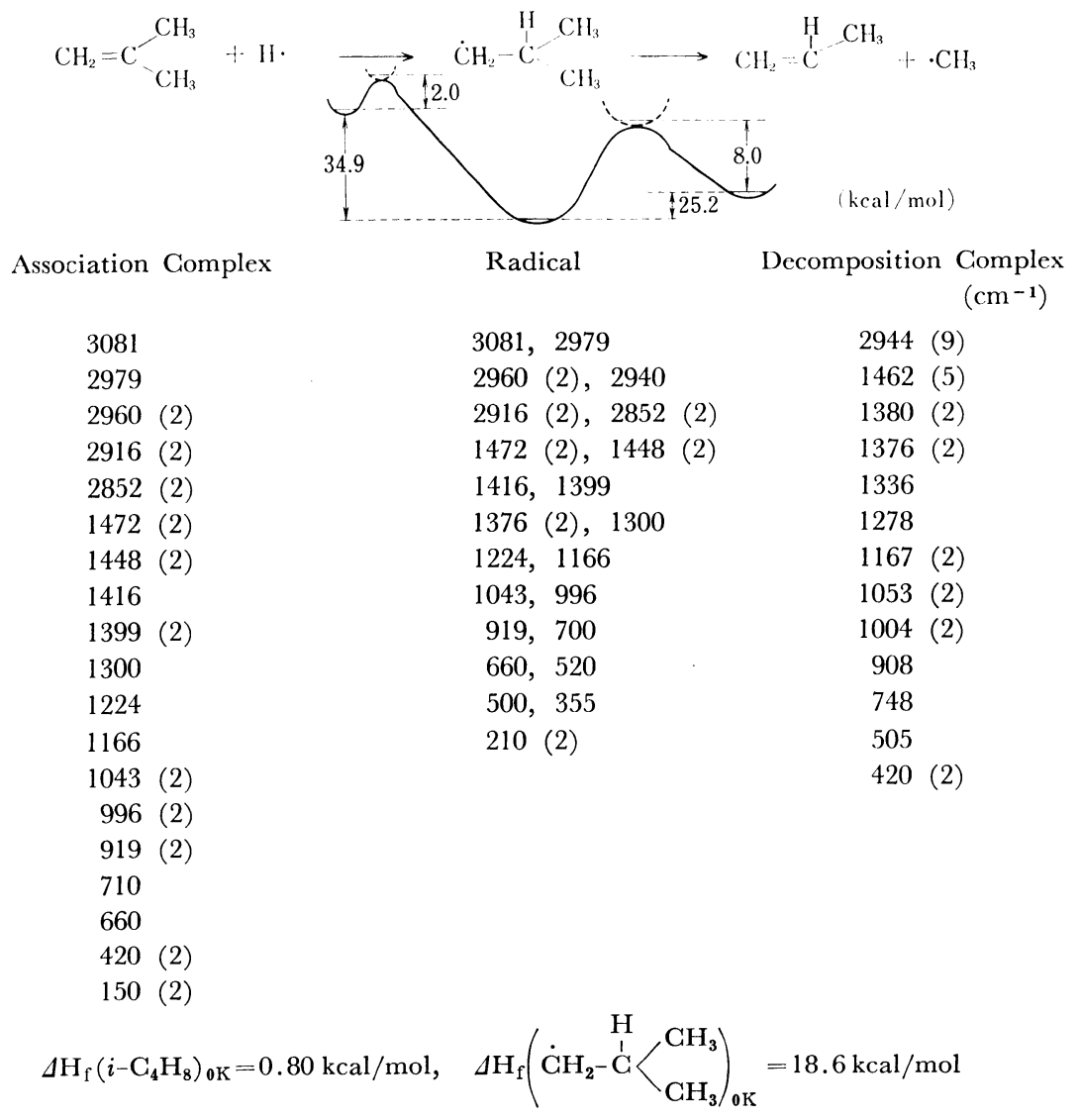


Appendix Vibration Models (2)

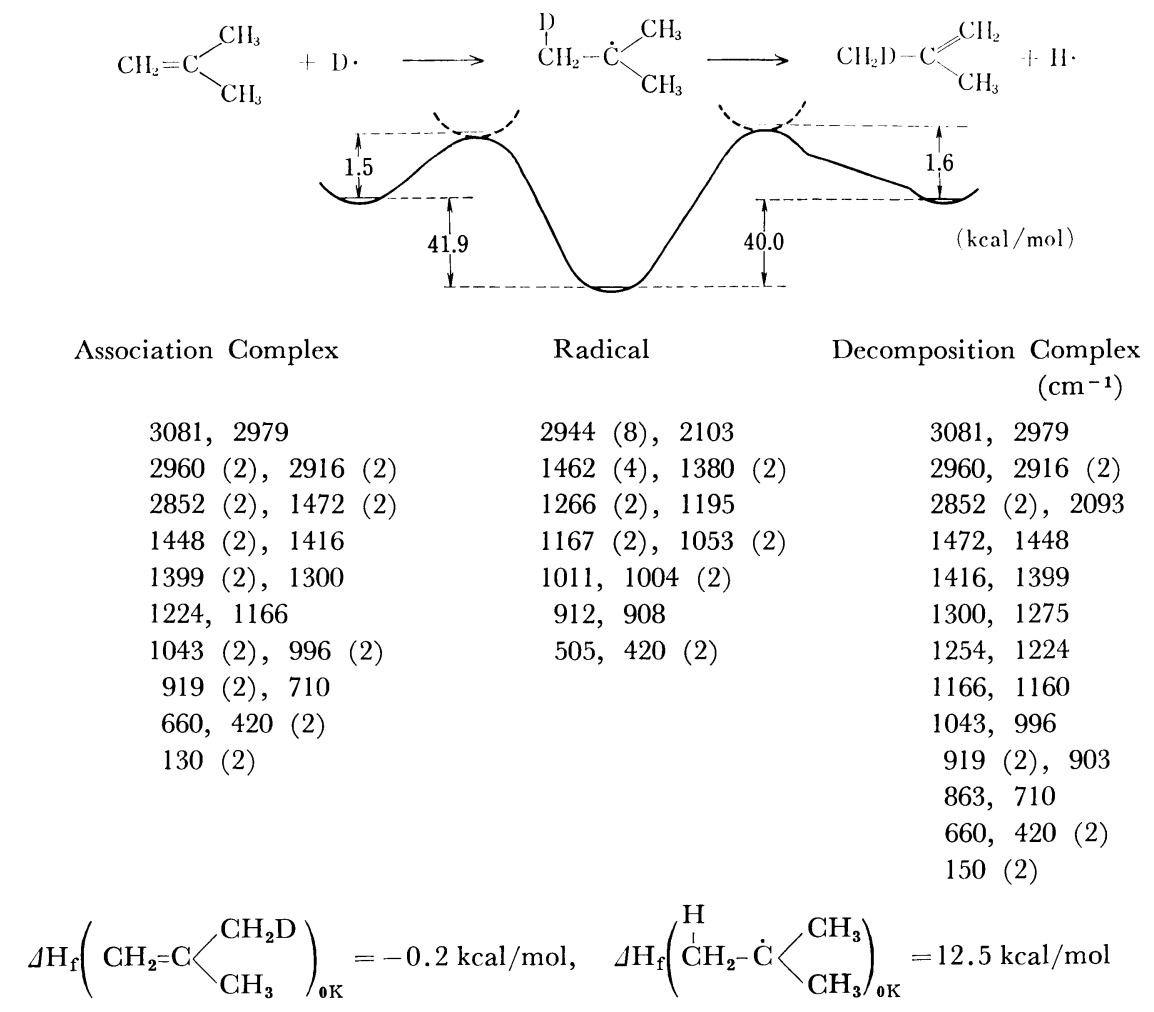

Appendix Vibration Models (3)

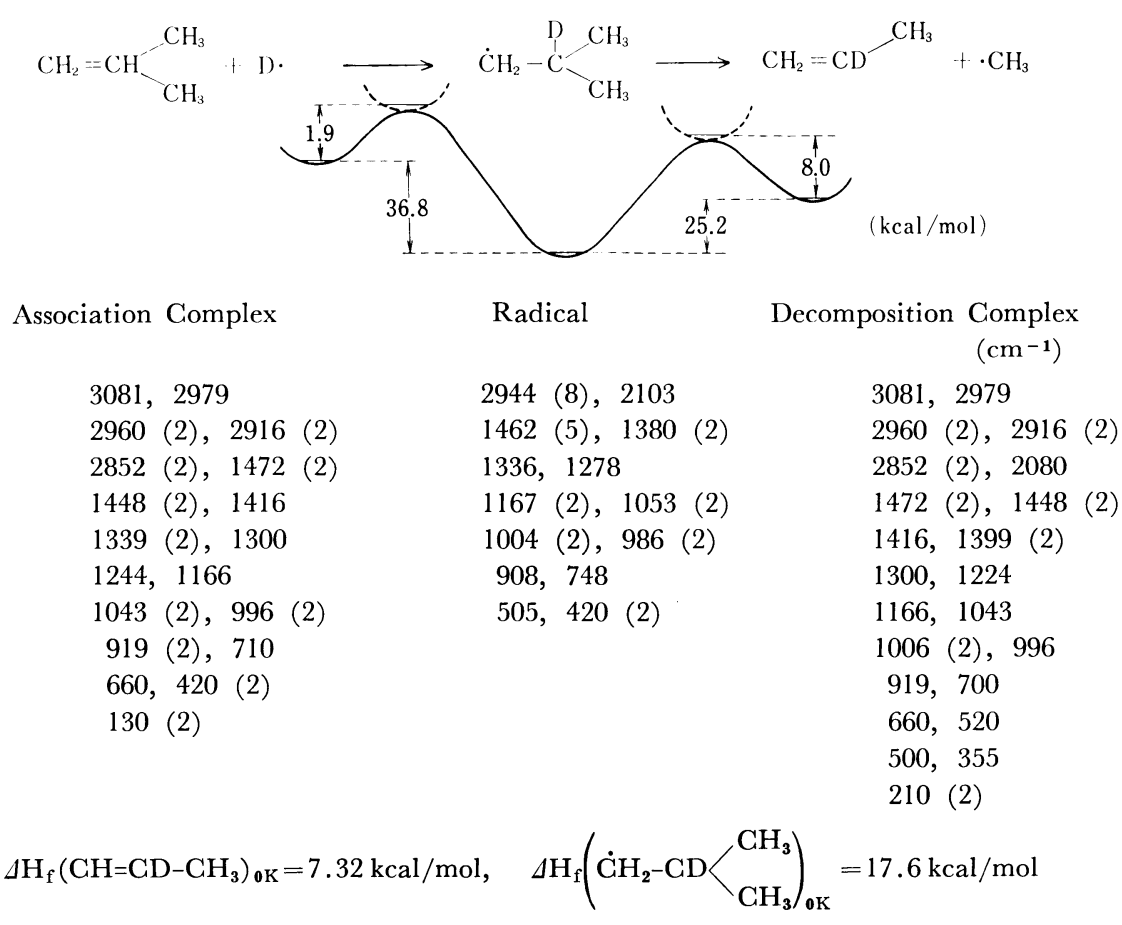




\title{
重水素存在下におけるインブテンの水素化分解速度
}

\author{
獚森 麇信*, 荒扑: 弘通*, 富永 博夫*
}

水素あるいは重水素存在下でイソブテンの高温熱分解反応の 研究を行った。嫦压不英流通反応容器を用い, 反応温度は 948 $\sim 1,023 \mathrm{~K}$, 滞留時閒は 1.0 4.5 秒, 水素（または重水素）/ イソブテン＝約 10 という条件で行った。主生成物は,メタン, エチレン，プロピレンであった。実験結果は Tables 1, 2 に示 した。生成物の分析はガスクロで, 生成物中の重水素分布はガ スクローマスで測定した。イソブテンの消失速度式は, イソブ テンに 1 次, 水素又は重水素に 0.5 次であった。得られた総括 反応速度定数は,

$$
\begin{gathered}
\left(k_{\text {obs. }}\right)_{\mathrm{H}_{2}}=10^{13.6^{ \pm 0.4}} \exp (-62,000 \pm 4,000 / \mathrm{RT}) \\
\left(k_{\text {obs. }}\right)_{\mathrm{D}_{2}}=10^{15.1^{ \pm 0.5}} \exp (-72,000 \pm 4,000 / \mathrm{RT}) \\
l^{1 / 2} / \mathrm{mol}^{1 / 2} \cdot \mathrm{sec}^{-1}
\end{gathered}
$$

Fig. 1 では，メタン $d_{0}$ の生成が注目すべきことで，これは， . $\mathrm{CH}_{3}+i-\mathrm{C}_{4} \mathrm{H}_{8} \longrightarrow \mathrm{CH}_{4}+i-\mathrm{C}_{4} \mathrm{H}_{7}$. の反応の寄与を示してい る。Fig. 2 では，反応初期にプロピレン $d_{0}$ がプロピレン $d_{1}$ より多く生成していることがわかる。Figs. 2,3 から，イソブ テンの重水素化（末端付加）速度が脱メチル（中心付加）速度 よりずっと速いことがわかる。 $\mathrm{CH}_{3}+\mathrm{D}_{2} \longrightarrow \mathrm{CH}_{3} \mathrm{D}+\mathrm{D} \cdot$ と $i-\mathrm{C}_{4} \mathrm{H}_{7} \cdot+\mathrm{D}_{2} \longrightarrow i-\mathrm{C}_{4} \mathrm{H}_{7} \mathrm{D}+\mathrm{D} \cdot$ の反応によって生じた D.の 大部分は, $\mathrm{D} \cdot+i-\mathrm{C}_{4} \mathrm{H}_{8} \longrightarrow i-\mathrm{C}_{4} \mathrm{H}_{7} \mathrm{D}+\mathrm{H} \cdot$ によって $\mathrm{H}$. 換され，このため $\mathrm{H} \cdot+i-\mathrm{C}_{4} \mathrm{H}_{8} \longrightarrow \mathrm{C}_{3} \mathrm{H}_{6}+\cdot \mathrm{CH}_{3}$ により，プロ ピレン $d_{\mathbf{0}}$ が反応初期に生成すると考えられる。反応が進行し

* 東京大学工学部合成化学科 (113 東京都交京区本郷 7-3-1)

\section{Keyword}

Deuteration, Isobutene, Isotope effect, Kinetics, Thermal hydrogenolysis $\tau d_{1}$ 体の割合が増すのは， $i-\mathrm{C}_{4} \mathrm{H}_{7} \mathrm{D}+\mathrm{H} \cdot \longrightarrow \mathrm{C}_{3} \mathrm{H}_{5} \mathrm{D}+\cdot \mathrm{CH}_{3}$ の寄与が増大するためと考元られる。以上の考察索まとめると，

$$
\begin{aligned}
& i-\mathrm{C}_{4} \mathrm{H}_{8} \longrightarrow i-\mathrm{C}_{4} \mathrm{H}_{7} \cdot+\mathrm{H} \cdot \\
& i-\mathrm{C}_{4} \mathrm{H}_{7} \cdot+\mathrm{H} \cdot \longrightarrow i-\mathrm{C}_{4} \mathrm{H}_{8} \\
& i-\mathrm{C}_{4} \mathrm{H}_{7} \cdot+\mathrm{D} \cdot \longrightarrow i-\mathrm{C}_{4} \mathrm{H}_{7} \mathrm{D} \\
& \mathrm{H} \cdot+i-\mathrm{C}_{4} \mathrm{H}_{8} \longrightarrow \mathrm{H}_{2}+i-\mathrm{C}_{4} \mathrm{H}_{7} . \\
& \mathrm{D} \cdot+i-\mathrm{C}_{4} \mathrm{H}_{8} \longrightarrow \mathrm{HD}+i-\mathrm{C}_{4} \mathrm{H}_{7} \cdot \\
& i-\mathrm{C}_{4} \mathrm{H}_{7} \cdot+\mathrm{D}_{2} \longrightarrow i-\mathrm{C}_{4} \mathrm{H}_{7} \mathrm{D}+\mathrm{D} . \\
& \mathrm{H} \cdot+i-\mathrm{C}_{4} \mathrm{H}_{8} \longrightarrow \mathrm{C}_{3} \mathrm{H}_{6}+\cdot \mathrm{CH}_{3} \\
& \mathrm{D} \cdot+i-\mathrm{C}_{4} \mathrm{H}_{8} \longrightarrow \mathrm{C}_{3} \mathrm{H}_{5} \mathrm{D}+\cdot \mathrm{CH}_{3} \\
& \mathrm{D} \cdot+i-\mathrm{C}_{4} \mathrm{H}_{8} \longrightarrow i-\mathrm{C}_{4} \mathrm{H}_{7} \mathrm{D}+\mathrm{H} \cdot \\
& \cdot \mathrm{CH}_{3}+\mathrm{D}_{2} \longrightarrow \mathrm{CH}_{3} \mathrm{D}+\mathrm{D} \cdot \\
& \cdot \mathrm{CH}_{3}+i-\mathrm{C}_{4} \mathrm{H}_{8} \longrightarrow \mathrm{CH}_{4}+i-\mathrm{C}_{4} \mathrm{H}_{7} . \\
& \mathrm{H} \cdot+\mathrm{D}_{2} \longrightarrow \mathrm{HD}+\mathrm{D} .
\end{aligned}
$$

同位体効果の大部分は，2-メチルアリルラジカルによって可 断をうける $\mathrm{H}-\mathrm{H} ， \mathrm{D}-\mathrm{D}$ 結合のゼロ点エネルギーの差による ものと考光られる。2-メチルアリルラジカルは, アリルラジカ ルよりさらに反応性が低いことから，同位体効果はプロピレ ン2）の時よりさらに大きくなることが期待され，実験的に支持 された。

RRKM によるホットラジカルの分解速度定数の計算結果を Table 3 に示した。計算では, 脱メチル反応速度は, 重水素化 反応速度よりずっと速い。しかし，実験結果では，脱メチル反 応の方が重水素化反応よりはるかに遅い。このことは, 脱メチ

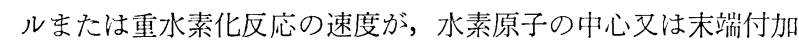
の速度によって決まることを示唆している。以上の結果はすべ て，遊離基連鎖反応機構の正当性を支持している。 